\title{
Retro-odontoid pseudotumor: a poorly recognized alteration of the craniocervical junction
}

\author{
(DiD)Andrew Vinícius de Souza Batista ${ }^{1}$ \\ (iD) Guilherme Brasileiro de Aguiar ${ }^{2}$ \\ (iD) efferson Walter Daniel2 \\ (iD) José Carlos Esteves Veiga ${ }^{3}$
}

1. Médico residente de Neurocirurgia da Faculdade de Ciências Médicas da Santa Casa de São Paulo, São Paulo, SP, Brasil.
2. Neurocirurgião titular da Sociedade Brasileira de Neurocirurgia; assistente da disciplina de
Neurocirurgia da Faculdade de Ciências Médicas da Santa Casa de São Paulo, São Paulo, SP, Brasil.
3. Neurocirurgião titular da Sociedade Brasileira de Neurocirurgia; professor livre-docente e chefe da disciplina de Neurocirurgia da Faculdade de Ciências Médicas da Santa Casa de São Paulo, São Paulo, SP, Brasil.

\section{SUMMARY}

INTRODUCTION: Retro-odontoid pseudotumor (ROP) is a rare disease that affects the atlantoaxial joint and, in general, is associated with local biomechanical alterations that may or may not cause instability.

METHODS: Descriptive study of the literature available in databases MEDLINE/PubMed, LILACS, and Scopus. The research was conducted in April 2019.

DISCUSSION: ROP is, possibly, a syndromic designation that encompasses a significant variety of diseases of the atlantoaxial joint. There are different pathophysiological mechanisms implicated in its genesis. The patients, almost in their entirety, present with severe myelopathy, and most of them are treated surgically, with the posterior decompression being the most commonly used method, with or without arthrodesis. Evolution is usually favorable.

CONCLUSION: The ROP is still poorly recognized as a differential diagnosis between the diseases of the cranial-cervical junction. The information available in the literature analyzed was based mainly on the study of reports or case series; therefore, it is insufficient to define conducts with a high level of scientific evidence.

KEYWORDS: Odontoid process/pathology. Atlanto-axial joint/pathology. Review.

\section{INTRODUCTION}

Retro-odontoid pseudotumors (ROP) are an infrequent disorder that involves the atlantoaxial joint. As a result of population aging (with the consequent appearance of degenerative changes in the cervical spine) and the use of imaging examinations on a larger scale - particularly of magnetic resonance -, the number of cases identified has increased ${ }^{1,2}$.

When present, expansive retro-odontoid lesions should draw attention to the possibility of coexisting rheumatopathies involving the atlantoaxial joint,

DATE OF SUBMISSION: 07-Sep-2019

DATE OF ACCEPTANCE: 25-Nov-2019

CORRESPONDING AUTHOR: Andrew Vinícius de Souza Batista

Rua Dr. Cesário Motta Jr., 112 - Faculdade de Ciências Médicas da Santa Casa de São Paulo, Vila Buarque, SP, Brasil - CEP 01221-020

Tel: +55 112176-7000

E-mail: andrewvsb@gmail.com 
particularly the subluxation observed in rheumatoid arthritis. Cases of ROP without subluxation or C1-C2 instability are rare $^{3,4}$.

Over the past decade, there was an increased understanding of the physiopathology of ROP, thus, patients started to be better grouped in order to determine the most appropriate treatment for each case. However, the data currently available in the literature are not sufficiently uniform to ensure the development of strong evidence. From this analysis, we understand that it is fundamental to have an organized presentation and discussion about the disease, its differential diagnoses, and therapeutic modalities to contribute to the clinical practice, particularly of neurosurgeons, orthopedists, and rheumatologists.

\section{METHODS}

A descriptive study of the literature available in the Medline/PubMed, Lilacs, and Scopus databases. The search was carried out using the terms "retro-odontoid pseudotumor", "retro-odontoid mass", and "cervical Pannus". Other variants and expressions found in articles from the search were included in order to sensitize the method. Works that were duplicated and whose content was not within the context studied were excluded. The search was carried out in April 2019.

\section{DISCUSSION}

One of the first descriptions using the therm "pseudotumor" in order to refer to a mass in the craniocervical junction was made by Sze et al. ${ }^{5}$ in 1986. This author reported the cases of three patients with expansive lesions of atypical presentation in that area.

However, the lesions involving this segment of cervical spine are classicaly described as pannus, in patients with rheumatoid arthritis. By definition, pannus is an inflammatory tissue that causes erosion of the subchondral bone and cartilage in the synovial joints. However, similar lesions in individuals without systemic inflammatory diseases has led to the discovery of a pathological entity characterized by the presence of a non-inflammatory mass composed predominantly of fibrocartilaginous tissue. Joint cysts of degenerative nature are described between pseudotumoral lesions in this region ${ }^{6}$.

Most studies found in the literature consists of case reports or case series. Thus, it is not possible to properly determine the prevalence and incidence of ROP in the population.

It is known, however, that patients with rheumatoid arthritis comprise the subgroup of higher risk for the disease. They may have their cervical spine affected as a consequence of the disease activity in more than $40 \%$ of the cases, and anterior atlantoaxial subluxation is the most common form of involvement $^{7}$. On the other hand, most of these patients do not develop ROP ${ }^{8}$. Thus, the disease is unusual ${ }^{1.8}$, especially if not associated with atlantoaxial instability ${ }^{9}$.

In addition to inflammatory rheumatopathies, other conditions that may be related include long-term hemodialysis, mucoid degeneration of the transverse ligament of the atlas ${ }^{10}$, trauma, os odontoideum ${ }^{11}$, deposition of crystals, and disc herniation ${ }^{12}$.

There is no clear physiopathological mechanism for ROP. In rheumatoid arthritis, the formation of the pannus is usually attributed to the release of proteases, which destroys the extracellular matrix of the cartilage, and the proliferation of fibroblast-like cells. It is possible that the genesis of tissue deposition in the retro-odontoid space in ROP - especially in the topography of the cruciate ligament band ${ }^{13}$ - holds some similarity to these phenomena.

Classically, the element that triggers the process is chronic instability in the atlantoaxial joint. Goel ${ }^{9}$ suggests that the origin of the lesion is related to an instability that begins in the facets and that involves excessive arching of the posterior longitudinal ligament (which predisposes its detachment), with a consequent periosteal reaction and formation of osteophytes.

On the other hand, cases of ROP without demonstrated atlantoaxial instability have been described ${ }^{3}$. A prospective study with 201 rheumatoid arthritis patients found an inverse relationship between the size of the mass and the atlantodental interval (which expresses the integrity of the transverse ligament and, therefore, the stability of the joint $)^{8}$.

One theory suggests that the change in the amplitude of movement between the occipital condyles and C3 interferes in the process. Chikuda et al. ${ }^{1}$ argued that the biomechanical change that occurs, for example, in the calcification of the anterior and posterior longitudinal ligaments and in ankylosis, can determine increased stress on the atlantoaxial complex due to the reduction of movement amplitude below that level. As a consequence, a process of damage and repair is initiated, resulting in the deposition of fibrocartilaginous 
material with ligament hypertrophy, involving mainly the transverse ligament. This theory explains the occurrence of ROP on subaxial spondylosis. In this process, the formation of a pseudotumor and the emergence of atlantoaxial instability can be simultaneous or not. Therefore, the hypothesis that patients with an expansive retro-odontoid lesion become symptomatic due to medullary compression before there are radiological signs of residual subluxation in C1-C2 is plausible.

Acknowledging the existence of distinct physiopathologies, Tanaka et al. ${ }^{14}$ classified ROP into three types, differentiating them primarily by etiology and findings on magnetic resonance imaging, and type 1 (secondary to atlantoaxial subluxation) is the most prevalent. Table 1 summarizes the author's classification, whose analysis allows us to discuss the theoretical limitations in its construction. In it, for example, are not included cases such as crowned dens syndrome, which cannot be objectively categorized using the basic mechanisms singled out by Tanaka et al. ${ }^{14}$.

The clinical presentation is variable, and the most common form is compressive cervical myelopathy, present in up to $100 \%$ of the cases of a series ${ }^{15}$. In the patients with ROP without atlantoaxial instability evaluated in a systematic review, 95\% evolved with progressive myelopathy ${ }^{16}$. There can also be mechanical neck pain, bulbar symptoms, and radiculopathy.

Among the differential diagnoses are neoplastic lesions and crowned dens syndrome. The latter is characterized by the presence of a significant inflammatory reaction (usually with increased acute-phase proteins), followed by the calcification of the ligaments around the odontoid process thanks to the deposition of hydroxyapatite or calcium pyrophosphate dihydrate. It usually responds to treatment with anti-inflammatory steroidal and non-steroidal drugs ${ }^{17}$. Some authors include crowned dens syndrome as one of the presentations of $\mathrm{ROP}^{16}$.
Clinical suspicion must be raised primarily for patients with inflammatory reumatopathy and signs of involvement of the cervical spine. Nevertheless, it should also be considered as a differential diagnosis for cervical myelopathy among the elderly.

The diagnosis is aided by imaging methods. Magnetic resonance imaging (MRI) is the main examination method because it provides more detailed information about the lesion (the radiological characteristics of ROP in MRI are described in Table 1 and shown in Figure 1), as well as the degree of involvement of adjacent structures, in particular, the spinal cord.

Computed tomography can contribute to a in-depth study of osseous components and is very useful for identifying calcifications in crowned dens syndrome.

Dynamic radiographs of the cervical spine are relevant because they determine the presence or absence of atlantoaxial instability through measures such as the atlantodental interval (ADI) and changes in the range of motion.

In cases in which there is still doubt as to the nature of the retro-odontoid lesion, a biopsy can be carried out to conduct an anatomopathological study. Upon analysis, ROP is composed of predominantly necrotic degenerated fibrocartilaginous tissue $^{18}$, which may contain a focal proliferation of blood vessels 4 .

Regarding treatment, in general, the surgical approach is used, consisting of the direct excision of the lesion or spinal cord decompression with or without arthrodesis ${ }^{19}$. Direct resection can be done via the transoral route or by posterior laminectomy (epidural or transdural).

Based on the pathophysiological aspects of ROP, it has been established that treatment with decompression and fixation (C1-C2 or occipital-cervical) is associated with better clinical and radiological evolution,

TABLE 1. CLASSIFICATION OF RETRO-ODONTOID PSEUDOTUMOR ACCORDING TO TANAKA

\begin{tabular}{l|l|l|l} 
& Type 1 & Type 2 & Type 3 \\
\hline Incidence & Frequent $^{\star}$ & Rare & Rare \\
\hline Etiology & Atlantoaxial subluxation & $\begin{array}{l}\text { Spondylosis } \\
\text { Ankylosis } \\
\text { OALL }\end{array}$ & Disc herniation \\
\hline Finding in MRI & $\begin{array}{l}\text { T1: hypo- or isointense } \\
\text { T2: heterogeneous (hyper- and hy- } \\
\text { pointense areas) }\end{array}$ & Same as in type 1 & $\begin{array}{l}\text { T1: hypo- or isointense } \\
\text { T2: Hypointense } \\
\text { Herniated C2-C3 disc, contiguous } \\
\text { with retro-odontoid space }\end{array}$ \\
\hline
\end{tabular}


particularly in cases where there is already documented pre-operative atlantoaxial instability. Some authors advocate simple decompression, without arthrodesis, for treating patients with ROP without atlantoaxial subluxation.

In our search, we found no well-controlled randomized clinical trials evaluating the effectiveness of one technique over the other. Kobayashi et al. ${ }^{20}$ compared, in a series of cases, two groups of patients treated by the posterior route (with and without fusion), and no statistical difference was found between them in relation to functional recovery measured by the JOA (Japanese Orthopaedic Association) score ${ }^{21}$. On the other hand, the groups were statistically different regarding the regression of the lesion on magnetic resonance imaging; it was greater among patients treated with arthrodesis. Other three series of cases comparing fusion and no fusion did not have the same results 1,22,23.

A systematic review performed by Robles \& Mundis ${ }^{16}$ summarized a strategy for defining the treatment method for these cases from their physiopathological mechanism, establishing surgery (with or without stabilization) as the standard treatment. However, oligosymptomatic cases and those without focal neurological deficits were not discussed. Special attention should be paid to the fact that about onethird of the patients previously described presented subaxial spondylosis ${ }^{14}$. Based on this, the reduction of excessive mechanical demand and of the range of motion of the atlantoaxial joint may contribute, at least partially, to the local progression of ROP. Thus, and taking into account that elderly patients have higher surgical risk, in patients with no documented instability and milder clinical presentations, without signs of compressive myelopathy, a cervical collar can be used. There are reports of the use of this strategy even for patients with atlantoaxial instability ${ }^{24}$, with a consequent reduction of ROP observed during follow-up by imaging exams. It is important to emphasize that the conservative approach needs to be followed-up periodically and re-discussed in case of changes in the course of the disease.

\section{CONCLUSION}

ROP is a rare disease usually associated with atlantoaxial subluxation, but its pathophysiological mechanisms are not yet fully understood. Its diagnosis is based on clinical, epidemiological, and imaging exams. In general, the treatment is surgical, which is the choice when there is C1-C2 instability. Currently, there is no evidence that the surgical treatment for ROP cases without instability in oligosymptomatic patients presents a greater benefit than the clinical follow-up. Well-controlled prospective, randomized studies can provide new data and conclusions in this regard, in order to guide the best approach for the management of these patients.

FIGURE 1. MAGNETIC RESONANCE SAGITTAL SECTIONS OF THE CERVICAL SPINE SHOWING EXPANSIVE LESION LOCATED POSTERIOR TO THE ODONTOID PROCESS, CHARACTERIZED BY THE PRESENCE OF HETEROGENEOUS SIGNAL IN T2 WEIGHTED IMAGE (A) AND ISO/ HYPOSIGNAL IN T1 (B). IN THIS CASE, SUBAXIAL SPONDYLOSIS IS NOTED, PREDOMINANTLY AFFECTING THE C5-C6-C7 SEGMENT, A FINDING THAT IS OBSERVED IN THE TANAKA TYPE 2 ROP. SOURCE: PERSONAL COLLECTION.
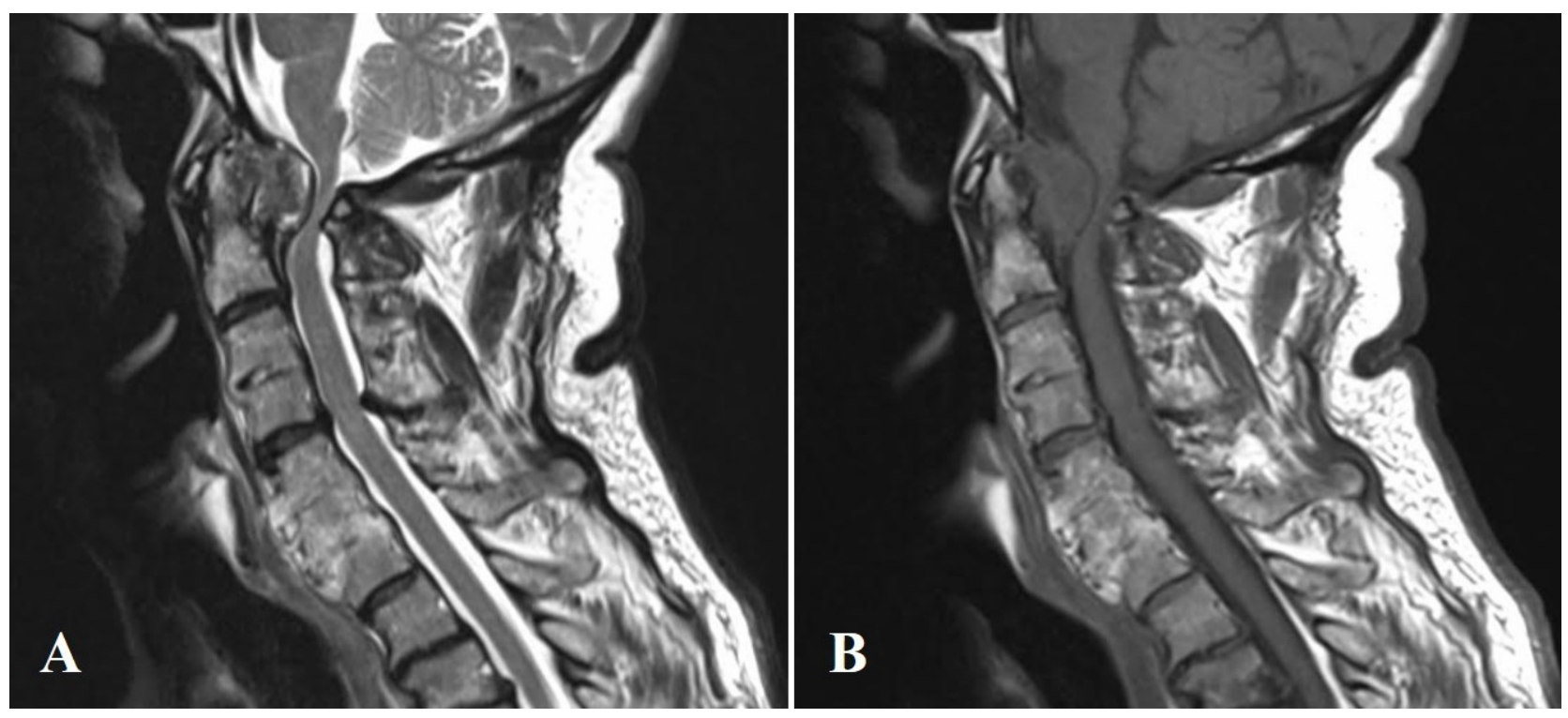


\section{Author's contributions}

1. Conception and design of the methodology: Andrew Vinícius de Souza Batista, Guilherme Brasileiro de Aguiar, José Carlos Esteves Veiga. 2. Literature search and selection of articles for review: Andrew Vinícius de Souza Batista, Guilherme Brasileiro de Aguiar, Jefferson Walter Daniel. 3. Analysis and interpretation of the selected articles: Andrew Vinícius de Souza Batista, Guilherme Brasileiro de Aguiar, Jefferson Walter Daniel. 4. Writing of the manuscript and standardization according to the requirements of the periodical: Andrew Vinícius de Souza Batista, Guilherme Brasileiro de Aguiar. 5. Critical review of the text: Jefferson Walter Daniel, José Carlos Esteves Veiga

\section{RESUMO}

INTRODUÇÃO: O pseudotumor retro-odontoide (PRO) é uma patologia rara que acomete a articulação atlantoaxial e, em geral, está associada a alterações biomecânicas locais que podem ou não causar instabilidade.

METOdologiA: Estudo descritivo da literatura disponível nas bases de dados Medline/PubMed, Lilacs e Scopus. A pesquisa foi realizada em abril de 2019.

DISCUSSÃO: O PRO é, possivelmente, uma designação sindrômica que abrange uma variedade significativa de doenças da articulação atlantoaxial. Existem diferentes mecanismos fisiopatológicos implicados em sua gênese. Os pacientes, quase em sua totalidade, apresentam quadro de mielopatia grave e a maioria deles é tratada cirurgicamente, sendo a descompressão posterior o método mais utilizado, com ou sem artrodese. A evolução costuma ser favorável.

CONCLUSÃO: O PRO ainda é pouco reconhecido como diagnóstico diferencial entre as doenças da junção crânio-cervical. As informações disponíveis na literatura analisada foram baseadas principalmente no estudo de relatos ou séries de casos, sendo, portanto, insuficientes para definir condutas com alto nivel de evidência científica.

PALAVRAS-CHAVE: Processo odontoide/patologia. Articulação atlantoaxial/patologia. Revisão.

\section{REFERENCES}

1. Chikuda K, Seichi A, Takeshita K, Shoda N, Ono T, Matsudaira K, et al. Radiographic analysis of the cervical spine in patients with retro-odontoid pseudotumors. Spine (Phila Pa 1976). 2009;34(3):E110-4.

2. Kakutani K, Doita M, Yoshikawa M, Okamoto K, Maeno K, Yurube T, et al. C1 laminectomy for retro-odontoid pseudotumor without atlantoaxial subluxation: review of seven consecutive cases. Eur Spine J.2003;22(5):1119-26.

3. Tominaga $H$, Setoguchi T, Nagano S, Kawamura I, Abematsu M, Yamamoto $T$, et al. Retro-odontoid mass without atlantoaxial instability causing cervical myelopathy: a case report of transdural surgical resection. Spinal Cord Ser Cases. 2016;2:16025.

4. Jun BY, Yoon KJ, Crockard A. Retro-odontoid pseudotumor in diffuse idiopathic skeletal hyperostosis. Spine (Phila Pa 1976). 2002;27(10):E266-70.

5. Sze G, Brant-Zawadzki MN, Wilson CR, Norman D, Newton TH. Pseudotumor of the craniovertebral junction associated with chronic subluxation: MR imaging studies. Radiology. 1986;161(2):391-4.

6. Ito T, Hayashi M, Ogino T. Retrodental synovial cyst which disappeared after posterior C1-C2 fusion: a case report. J Orthop Surg (Hong Kong). 2000;8(1):83-7.

7. Zhang T, Pope J. Cervical spine involvement in rheumatoid arthritis over time: results from a meta-analysis. Arthritis Res Ther. 2015;17:148.

8. Dohzono S, Suzuki A, Koike T, Takahashi S, Yamada K, Yasuda H, et al. Factors associated with retro-odontoid soft-tissue thickness in rheumatoid arthritis. J Neurosurg Spine. 2016;25(5):580-5.

9. Goel A. Retro-odontoid mass: an evidence of craniovertebral instability. J Craniovertebr Junction Spine. 2015;6(1):6-7.

10. Yanni DS, Halim AY, Alexandru D. Odontoid pseudotumor and serial postfusion radiographic evaluation in a patient with a C1-2 mass. J Neurosurg Spine. 2015;22(6):605-10.

11. Chang H, Park JB, Kim KW, Choi WS. Retro-dental reactive lesions related to development of myelopathy in patients with atlantoaxial instability secondary to Os odontoideum. Spine (Phila Pa 1976). 2000;25(21):2777-83.

12. Rosenberg WS, Rosenberg AE, Poletti CE. Cervical disc herniation presenting as a mass lesion posterior to the odontoid process. Report of two cases. Neurosurg. 1991;75(6):954-9.
13. Yamaguchi I, Shibuya S, Arima N, Oka S, Kanda Y, Yamamoto T. Remarkable reduction or disappearance of retroodontoid pseudotumors after occipitocervical fusion. Report of three cases. | Neurosurg Spine. 2006;5(2):156-60.

14. Tanaka S, Nakada M, Hayashi Y, Mohri M, Uchiyama N, Hamada I. Retro-odontoid pseudotumor without atlantoaxial subluxation. J Clin Neurosci. 2010;17(5):649-52.

15. Barbagallo GM, Certo F, Visocchi M, Palmucci S, Sciacca G, Albanese V. Disappearance of degenerative, non-inflammatory, retro-odontoid pseudotumor following posterior C1-C2 fixation: case series and review of the literature. Eur Spine J. 2013;22(Suppl 6):S879-88.

16. Robles LA, Mundis GM. Retro-odontoid pseudotumor without radiologic atlantoaxial instability: a systematic review. World Neurosurg. 2019;121:100-10.

17. Shikino K, Ota T, Ikusaka M. Crowned dens syndrome. Am J Med. 2017;130(3):e111-2.

18. Oohori Y, Seichi A, Kawaguchi H, Tajiiri Y, Oda H, Nakamura K. Retroodontoid pseudotumor resected by a high cervical lateral approach in a rheumatoid arthritis patient: a case report. J Orthop Sci. 2004;9(1):90-3.

19. $\mathrm{Yu} \mathrm{SH}$, Choi HJ, Cho WH, Cha SH, Han IH. Retro-odontoid pseudotumor without atlantoaxial subluxation or rheumatic arthritis. Korean | Neurotrauma. 2016;12(2):180-4.

20. Kobayashi K, Imagama S, Ando K, Nishida Y, Ishiguro N. Post-operative regression of retro-odontoid pseudotumors treated with and without fusion. Eur Spine J. 2018;27(12):3105-12.

21. Japanese Orthopaedic Association. Scoring system for cervical myelopathy. J Jpn Orthop Assoc. 1994;68:490-503.

22. Arima H, Murata H, Hasegawa T. Treatment of retro-odontoid pseudotumor. Report of five cases. Rinsyo Seikei-Geka. 2013;48:81-5.

23. Tominaga F, Shirasawa K, Yamashita A. Operation for retro-odontoid pseudotumor. Seikei-Geka. 2015;66:311-4.

24. Klas PG, Wilson J, Cusimano MD. Regression of degenerative retro-odontoid pseudotumor treated in a collar. Can | Neurol Sci. 2018;45(5):599-600. 